Psihologijske teme, 27 (2018), 3, 543-559

Izvorni znanstveni rad - UDK - 159.97.072-055.26

616.89-085.851-055.26

doi:https://doi.org/10.31820/pt.27.3.10

\title{
Coping Styles Associated with Post-Traumatic Stress and Depression Symptoms Following Childbirth in Croatian Women
}

\author{
Sandra Nakić Radoš ${ }^{1}$, Alexandra Sawyer ${ }^{2}$, Susan Ayers ${ }^{3}$, and Erin Burn ${ }^{4}$ \\ ${ }^{1}$ Catholic University of Croatia, Department of Psychology, Croatia \\ ${ }^{2}$ University of Brighton, School of Health Sciences, United Kingdom \\ ${ }^{3}$ University London, School of Health Sciences, Centre for Maternal and \\ Child Health Research, United Kingdom \\ ${ }^{4}$ East London NHS Foundation Trust, United Kingdom
}

\begin{abstract}
Childbirth is a normative event in a woman's life and is considered as a positive event. However, one in three women perceive childbirth as a physical threat to themselves or their new-born and 3\% of women develop posttraumatic stress disorder (PTSD) following childbirth. Poor coping strategies have been associated with PTSD following childbirth. However, previous studies mainly utilised unidimensional measures of coping strategies, therefore, it remains to be investigated which specific dimensions of coping are more predictive of PTSD after childbirth. The aims of this study were to explore whether women in Croatia report PTSD symptoms following childbirth, and how different coping styles were related to PTSD and depression symptoms. Women $(N=160)$ who gave birth in the last two years, completed an online questionnaire measuring PTSD symptoms (Impact of Event Scale - IES), postnatal depression symptoms (Edinburgh Postnatal Depression Scale - EPDS) and coping styles (Brief Cope). In this sample, 1.9\% reported severe PTSD symptoms following childbirth and $21.9 \%$ reported depression symptoms. Many women (66.7\%) with PTSD symptoms reported depression symptoms. On the other hand, $28.6 \%$ of women with depression symptoms also reported PTSD symptoms, showing that there is a higher co-morbidity of PTSD and depression than vice versa. Avoidant coping styles, specifically, denial and self-blame were positively correlated with both PTSD and depression symptoms. Moreover, of avoidant coping styles, behavioural disengagement was positively correlated with PTSD symptoms only, while self-distraction was positively correlated with depression symptoms only. Also, lower levels of planning and higher levels of emotional support were related to higher levels of depression. However, after controlling for postnatal psychopathology symptoms, coping styles were not significant predictors of PTSD symptoms, but self-blame was a significant predictor of depression symptoms. Psychopathological symptoms following childbirth are reported by Croatian women and are related to coping styles.
\end{abstract}

Sandra Nakić Radoš, Department of Psychology, Catholic University of Croatia, Ilica 242, 10000 Zagreb, Croatia. E-mail: snrados@unicath.hr

This study was partially funded by a fellowship from the British Scholarship Trust granted to the first author (SNR). 
The avoidant coping style, self-blame, is particularly associated with depression symptoms. Future studies should explore predictors of postpartum PTSD in Croatian women in more representative samples during pregnancy and with the follow-up after childbirth. Also, screening for postnatal psychopathological symptoms should be performed both for depression and PTSD symptoms.

Keywords: post traumatic stress disorder, PTSD, childbirth, depression, coping

\section{Introduction}

Childbirth is considered a normative event in a woman's life and is a positive experience for many women. However, childbirth has an amount of inherent risk with maternal mortality occurring in 16 in every 100,000 births in developed regions of the world (World Health Organization [WHO], 2014). Approximately one-third of women perceive childbirth as a physical threat to themselves or their newborn (Boorman, Devilly, Gamble, Creedy, \& Fenwick, 2013; Creedy, Shochet, \& Horsfall, 2000; Czarnocka \& Slade, 2000; Soet, Brack, \& Dilorio, 2003). Exposure to actual or threatened death or serious injury is specified in DSM-5 Criterion A as necessary to precipitate the development of posttraumatic stress disorder (PTSD) (American Psychiatric Association, 2013). A recent meta-analysis showed that the prevalence rates of PTSD in the first year following childbirth were $3.1 \%$ in community samples and $15.7 \%$ in high-risk samples (Grekin \& O'Hara, 2014).

Several risk factors for the development of PTSD following childbirth have been identified in a meta-analysis (Ayers, Bond, Bertullies, \& Wijma, 2016). One of the factors most strongly associated with PTSD is depression. Other risk factors include fear of birth, trait anxiety (Czarnocka \& Slade, 2000; Soet et al., 2003) and anxiety sensitivity (Verreault et al., 2012). During labour and birth risk factors include inadequate or low support from the staff (Creedy et al., 2000; Czarnocka \& Slade, 2000), instrumental deliveries, emergency caesarean section (Creedy et al., 2000; Söderquist, Wijma, Thorbert, \& Wijma, 2009), and lack of control (Andersen, Melvaer, Videbech, Lamont, \& Joergensen, 2012; Denis, Parant, \& Callahan, 2011; Olde, van der Hart, Kleber, \& van Son, 2006; Tedstone \& Tarrier, 2003).

A recent meta-analysis showed that poor coping strategies have also been associated with postnatal PTSD (Ayers et al., 2016). For example, poor coping with stress during pregnancy (Söderquist et al., 2009; Soet et al., 2003) and dissociation during labour (Olde et al., 2005) were identified as significant predictors of PTSD symptoms following childbirth. In a cognitive model of PTSD (Ehlers \& Clark, 2000), dysfunctional coping styles have been highlighted as an individual vulnerability factor that can contribute to the adverse cognitive processing of a traumatic event and its sequelae, promoting persistent PTSD. First, negative appraisals of the traumatic experience and initial PTSD symptoms produce negative emotions, such as depression and anxiety, and foster the use of dysfunctional coping 
styles, which in turn promote the maintenance of the PTSD symptoms (Ehlers \& Clark, 2000).

Coping can be categorised as problem-focused coping, which is oriented towards problem-solving, and emotion-focused coping, which is oriented towards diminishing emotional distress (Folkman \& Lazarus, 1980 ). In addition, Endler and Parker (1990) proposed an avoidant coping strategy, which describes the avoidance of stressful situations via cognitive changes and different activities. Of these coping styles, avoidant coping has been found to be a significant predictor of PTSD symptoms in students who experienced a traumatic loss of a close person (Schnider, Elhai, \& Gray, 2007). Previous studies that examined coping in PTSD following childbirth mainly utilised unidimensional measures of coping abilities (Söderquist et al., 2009; Soet et al., 2003). In a recent study of different coping dimensions and PTSD symptoms in parents of preterm and full-term new-borns (Ghorbani, Dolatian, Shams, Alavi-Majd, \& Travakolian, 2014), parents of preterm new-borns reported more use of all types of coping strategies in comparison with parents of full-term newborns. However, it remains to be investigated which specific dimensions of coping are more important in PTSD after childbirth.

Every year about 40,000 women give birth in Croatia. All births are attended by a skilled health professional (World Health Organisation - WHO, 2013). A home birth or an elective caesarean section is not offered to women on demand. An increase in the caesarean section rate has been observed in the last decade (Rodin, 2017). The caesarean section rate is currently $23 \%$ and assisted vaginal birth rate is $1.4 \%$ (Rodin, 2017). The maternal mortality rate of 8 per 100000 is somewhat lower than the average rate of 12 for countries in developed regions (World Health Organisation WHO, 2015). Research on perinatal mental health in Croatia is still quite rare. Studies have mainly focused on anxiety during pregnancy, such as fear of childbirth or anxiety due to prenatal diagnostic procedures (Brajenović-Milić, Martinac Dorčić, Kuljanić, \& Petrović, 2010; Jokić-Begić, Žigić, \& Nakić Radoš, 2013; Nakić Radoš, Košec, \& Gall, 2013; Nakić, Tadinac, \& Herman, 2009) and postnatal depression (PND) (Čuržik \& Jokić-Begić, 2012; Nakić Radoš, Tadinac, \& Herman, 2016; Reić Ercegovac \& Penezić, 2011). A recent study examined predictors of PTSD symptoms prospectively and showed that higher levels of symptoms immediately after childbirth were significant predictors for higher levels of PTSD symptoms two months after childbirth (Srkalović Imširagić, Begić, Šimičević, \& Bajić, 2017). Another recent study compared post-traumatic growth after childbirth in Croatian and UK women (Sawyer, Nakić Radoš, Ayers, \& Burn, 2015) and showed that one in three women reported a moderate level of growth. Moreover, growth was predicted by coping strategies, where higher levels of growth were predicted by higher levels of problem- and emotion-focused coping in UK women but the higher levels of avoidance in Croatian women. However, none of these studies examined PTSD symptoms in relation to coping. Given that there is a lack of data on specific dimensions of coping and their relation to PTSD, the aim of the current study was to 
examine the association between different coping styles and PTSD symptoms. Given the strong association between PTSD and depression, this study also aimed to examine coping in relation to depression. It is hypothesised that avoidant coping styles would be associated with higher levels of PTSD.

\section{Methods}

\section{Participants}

A sample of 160 women was recruited through the internet and by word of mouth in Croatia. Women were eligible to participate if they were over 18 and had given birth within the last two years. Seventeen participants were excluded from the final analysis due to incomplete responses or time since birth being less than one month or over two years. The mean age of mothers was 31.3 years $(S D=4.2$, range 22 - 41) and the average time since giving birth was 11 months $(S D=6.5$, range 1 24). All participants gave their informed consent prior to entering the study.

The sample characteristics are shown in Table 1 . The majority of women were married, highly educated and employed. The majority were primiparous and had a normal vaginal delivery. Eighteen women (11.3\%) stated that they had been diagnosed or treated for psychological problems since the baby was born. Only two women $(1.3 \%)$ were currently taking medication for psychological problems.

Table 1.

Main Demographics and Obstetric Variables of the Sample $(N=160)$

\begin{tabular}{llrr}
\hline & & $N$ & \multicolumn{1}{c}{$\%$} \\
\hline Marital status & Married & 140 & 87.5 \\
& Living with partner & 14 & 8.8 \\
& Single & 6 & 3.7 \\
\hline Education level & Primary school & 27 & 16.9 \\
& High school & 34 & 21.2 \\
& University & 99 & 61.9 \\
\hline Employment & yes & 136 & 85.0 \\
& no & 24 & 15.0 \\
\hline Number of children & One & 103 & 64.4 \\
& Two & 52 & 32.5 \\
& Three & 5 & 3.1 \\
\hline Birth & normal vaginal delivery & 126 & 78.8 \\
& assisted delivery & 5 & 3.1 \\
& emergency caesarean section & 23 & 14.4 \\
& planned caesarean section & 6 & 3.8 \\
\hline
\end{tabular}




\section{Instruments}

The Impact of Events Scale (IES: Horowitz, Wilner, \& Alvarez, 1979) is used to assess posttraumatic stress reactions in response to a severe or traumatic event(s). The IES has been recognised as a useful instrument in measuring traumatic stress following childbirth (Czarnocka \& Slade, 2000; Lyons 1998a). Moreover, it has been documented to be a more satisfactory instrument to measure stress reactions following childbirth than its revised counterpart, the IES-R (Olde, Kleber, van der Hart, \& Pop, 2006). The IES consists of 15 items measuring avoidance ( 8 items) and intrusion ( 7 items). The items are rated on a 4-point scale, ranging from 0 - 5 on the frequency that the items have been experienced as a result of childbirth, over the seven days prior to testing $(0=$ not at all, $1=$ rarely, $3=$ sometimes, $5=$ often $)$. This yields a maximum score of 75 . Scores are graded on a continuum, with scores under 15 classed as subclinical, 16 - 25 as minor, 26 - 44 as moderate and severe scores are classified as 45 and over (Corneil, Beaton, \& Murphy, 1999). The overall reliability for the total inventory was high $(\alpha=.86)$, as was the internal consistency of the scales (intrusion, $\alpha=.78$ and avoidance, $\alpha=.82$ ). Furthermore, test-retest reliability was high at .87 (Horowitz et al., 1979). The scale has been previously translated and validated for use in a Croatian sample (Powell \& Duraković-Belko, 2002; Ljubotina $\&$ Muslić, 2003). In this study the internal consistency was $\alpha=.91$ for the total inventory, and $\alpha=.85$ and $\alpha=.84$ for avoidance and intrusion respectively, indicating high reliability.

The Edinburgh Postnatal Depression Scale (EPDS: Cox, Holden, \& Sagovsky, 1987 ) is a ten-item inventory which is used to assess the prevalence of depression symptoms over the previous week. The items are rated on a 4-point scale ranging from $0-3$, which yields a maximum score of 30, with greater scores signifying a greater level of depression symptoms. The overall reliability for the EPDS was high $\alpha=.88$ (Cox et al., 1987). In the present study, this is comparable at $\alpha=.86$. The EPDS has also been previously validated and successfully utilised within a Croatian sample where it was shown that the cut-off score of $\geq 9$ had the optimal sensitivity and specificity (Nakić Radoš et al., 2013b).

The Brief Cope questionnaire (Carver, 1997) was used to ascertain the different types of coping strategies utilised in response to a stressful event. The scale consists of 28 items, which are subdivided into 14 scales measuring differing coping strategies. These were further subdivided into three coping categories according to Schnider et al. (2007). The coping strategies and their associative coping scales are as follows: Avoidant Coping (incorporating; self-distraction, denial, behavioural disengagement, self-blame and substance abuse), Problem-focused Coping (incorporating; active coping, planning, instrumental support, religion) and Emotionfocused Coping (incorporating; venting, positive reframing, humour, acceptance and emotional support). Ratings are completed on a 4-point scale ranging from 1 ( $I$ haven't been doing this at all) to 4 (I've been doing this a lot). Reliability of Approach 
Coping subscale was $\alpha=.86$ and of Avoidant Coping subscale was $\alpha=.75$. The Brief Cope has also been verified in a Croatian sample, where a similar factor structure to the original inventory was observed (Hudek-Knežević, Kardum, \& Vukmirović, 1999).

Demographic and obstetric data. This comprised of standard demographic questions such as age, marital status, education level, ethnicity, and religion, as well as obstetric questions such as parity, type of delivery, and number of months since the last baby was born. Information on previous and current psychological problems, and whether medication was being taken for current psychological problems, were also obtained.

\section{Procedure}

This was a cross-sectional online questionnaire study. The study was conducted as part of a larger cross-cultural study in the UK and Croatia. The URL was posted on a Croatian website for parents (www.roda.hr), a social networking site (www.facebook.com), and was distributed through word of mouth.

Ethical approval for the larger study was obtained from the University of Sussex (UK) ethics committee. Participants were provided with information about the study and were ensured that their responses would be confidential, and they could withdraw from the study at any time. Questionnaire responses were entered automatically into a password-protected database.

\section{Statistical Analyses}

Data screening indicated that PTSD symptoms were positively skewed. Transformations did not normalise the data. However, skewness and kurtosis indices were below 3 and 10, respectively, as proposed by Kline (2005) to be considered as complying with the assumption of normality. Non-parametric statistics were used to test associations between the IES and other psychological measures (Spearman's correlation) and hierarchical regression analysis was performed on non-transformed data. A minimum of $p<.05$ is set for statistical significance in all analyses.

\section{Results}

Descriptive statistics for PTSD and depression symptoms, and coping are presented in Table 2. The average values for PTSD and depression symptoms obtained in this sample are classified as subclinical. However, a wide range of scores was observed for PTSD symptoms and depression symptoms, whilst the full range of scores was observed for coping. Ten women (6.3\%) had minor PTSD symptoms, 12 women $(7.5 \%)$ had moderate PTSD symptoms, and 3 women (1.9\%) had severe 
PTSD symptoms following childbirth. Of women who had moderate and severe PTSD symptoms, $66.7 \%$ also had clinically significant symptoms of depression (EPDS score $\geq 9$ ). On the other hand, $21.9 \%$ of all women had PND symptoms (35/160), out of which 28.6\% had also present PTSD symptoms (10/35). In total, $25.0 \%$ women scored positive either for PTSD or PND symptoms $(n=40)$.

Table 2.

Descriptives for PTSD and Depression Symptoms, and for COPE

\begin{tabular}{lrrrcc}
\hline & $M$ & $S D$ & Median & Range & $\begin{array}{c}\text { Theoretical } \\
\text { range }\end{array}$ \\
\hline PTSD symptoms (IES) & & & & & \\
\hline Avoidance & 2.93 & 5.52 & 0 & $0-30$ & $0-40$ \\
Intrusion & 4.42 & 6.11 & 1 & $0-27$ & $0-35$ \\
Total scale & 7.35 & 10.95 & 3 & $0-57$ & $0-75$ \\
Depression symptoms (EPDS) & 5.96 & 4.72 & 5 & $0-25$ & $0-30$ \\
\hline COPE & & & & & \\
\hline Avoidant coping & 18.14 & 4.35 & 18 & $10-40$ & $10-40$ \\
self-distraction & 4.88 & 1.54 & 5 & $2-8$ & $2-8$ \\
denial & 2.98 & 1.23 & 2.5 & $2-8$ & $2-8$ \\
behavioural disengagement & 3.43 & 1.39 & 3 & $2-8$ & $2-8$ \\
self-blame & 4.55 & 1.71 & 4 & $2-8$ & $2-8$ \\
substance use & 2.31 & 0.83 & 2 & $2-8$ & $2-8$ \\
Problem-focused coping & 22.11 & 4.29 & 22 & $9-32$ & $8-32$ \\
active coping & 6.77 & 1.16 & 7 & $3-8$ & $2-8$ \\
planning & 6.79 & 1.42 & 7 & $2-8$ & $2-8$ \\
religion & 4.09 & 1.96 & 4 & $2-8$ & $2-8$ \\
instrumental support & 5.73 & 1.72 & 6 & $2-8$ & $2-8$ \\
Emotion-focused coping & 29.35 & 5.45 & 30 & $10-40$ & $10-40$ \\
venting & 6.14 & 1.47 & 6 & $2-8$ & $2-8$ \\
positive reframing & 5.89 & 1.59 & 6 & $2-8$ & $2-8$ \\
humour & 5.34 & 1.86 & 6 & $2-8$ & $2-8$ \\
acceptance & 6.24 & 1.32 & 6 & $2-8$ & $2-8$ \\
emotional support & 5.74 & 1.71 & 6 & $2-8$ & $2-8$ \\
\hline
\end{tabular}

Notes: IES - Impact of Event Scale; EPDS - Edinburgh Postnatal Depression Scale

Analyses of demographic and obstetric variables, including time since giving birth, found no significant associations between these variables and postnatal psychopathology symptoms. Table 3 shows correlations between PTSD symptoms, depression symptoms, and coping strategies. Depression symptoms were positively correlated with PTSD symptoms. Avoidant coping strategies were positively correlated with PTSD symptoms. Specifically, more use of denial, behavioural disengagement, and self-blame as ways of coping were associated with higher levels of PTSD symptoms. Problem- and emotion-focused coping were not associated with PTSD symptoms. Avoidant coping strategies were also positively correlated with 
depression symptoms. Specifically, higher levels of depression symptoms were related to higher levels of self-distraction, denial, and self-blame. Of problem- and emotion-focused coping, higher levels of depression symptoms were associated with lower level of planning and higher level of emotional support.

Table 3 .

Spearman's Correlations between PTSD Symptoms (Measured by IES) and Depression Symptoms and Coping Strategies

\begin{tabular}{lcccc}
\hline & \multicolumn{3}{c}{ IES } & \multirow{2}{*}{ EPDS } \\
\cline { 2 - 3 } & Avoidance & Intrusion & Total score & \\
\hline Depression symptoms (EPDS) & $.31^{* *}$ & $.40^{* *}$ & $.38^{* *}$ & - \\
\hline COPE & & & & \\
\hline Avoidant coping (total) & $.18^{*}$ & $.20^{*}$ & $.21^{* *}$ & $.35^{* *}$ \\
self-distraction & .08 & .04 & .07 & $.22^{* *}$ \\
denial & .12 & $.19^{*}$ & $.19^{*}$ & $.23^{* *}$ \\
behavioural disengagement & $.17^{*}$ & $.17^{*}$ & $.19^{*}$ & .15 \\
self-blame & .15 & $.18^{*}$ & $.17^{*}$ & $.33^{* *}$ \\
substance use & .02 & .06 & .04 & .06 \\
\hline Problem-focused coping (total) & -.03 & .02 & -.01 & -.01 \\
active coping & -.04 & -.10 & -.11 & -.06 \\
planning & -.10 & -.11 & -.11 & $-.16^{*}$ \\
religion & .00 & .13 & .10 & .08 \\
instrumental support & .05 & .07 & .05 & .07 \\
\hline Emotion-focused coping (total) & -.09 & -.11 & -.11 & -.12 \\
venting & -.00 & -.05 & -.04 & .07 \\
positive reframing & -.07 & -.09 & -.10 & -.14 \\
humour & -.12 & -.12 & -.13 & -.18 \\
acceptance & -.11 & -.07 & -.08 & -.10 \\
emotional support & .13 & .10 & .11 & $.22^{* *}$ \\
\hline
\end{tabular}

Notes: IES - Impact of Event Scale, EPDS - Edinburgh Postnatal Depression Scale ${ }^{*} p<.05 ;{ }^{* *} p<.01$.

Two hierarchical regression analyses were performed with PTSD and depression symptoms as criteria and coping as predictors (Table 4). In the first step postnatal psychopathology symptoms were controlled for (either depression or PTSD symptoms, respectively), which explained $19.2 \%$ of symptoms variance. In the second step, coping was entered. This explained only $0.5 \%$ of PTSD symptoms variance which was not significant. However, coping styles explained additional $11.5 \%$ of depression symptoms variance which was significant, and self-blame was identified as a significant predictor. 
Table 4.

Prediction of PTSD Symptoms and Depression Symptoms

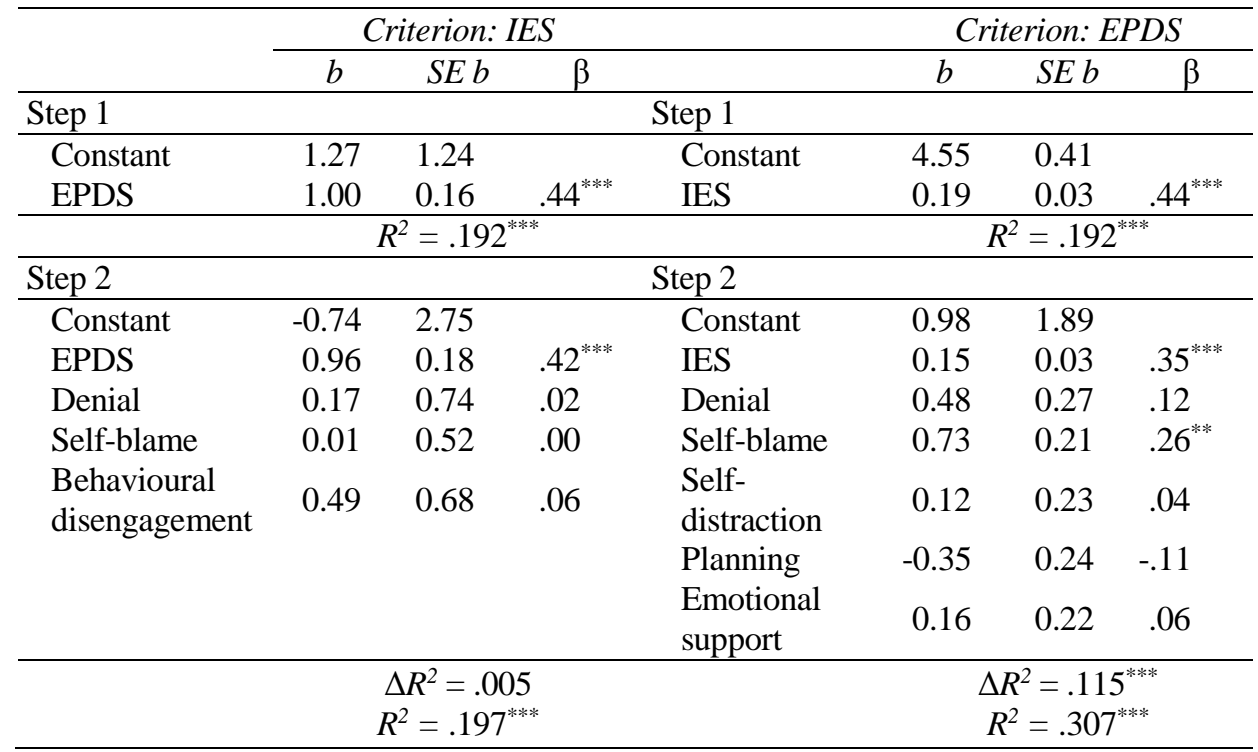

Notes: IES - Impact of Event Scale; EPDS - Edinburgh Postnatal Depression Scale ${ }^{*} p<.05 ;{ }^{* *} p<.01 ;{ }^{* * *} p<.001$.

\section{Discussion}

To the authors' knowledge, this is the first study to explore how specific coping styles are related to PTSD and depression symptoms following childbirth. In this sample, $1.9 \%$ of women had severe PTSD symptoms. Also, high comorbidity of PTSD and PND symptoms was established and avoidant coping styles were found to correlate with postnatal psychopathology symptoms.

Although the current study focused on symptoms and not a diagnosis of PTSD, the prevalence of $1.9 \%$ of women with severe PTSD symptoms is consistent with prevalence rates found during the first postnatal year in other studies (Alcorn, O'Donovan, Patrick, Creedy, \& Devilly, 2010; Denis et al., 2011; White, Matthey, Boyd, \& Barnett, 2006). The results of the current study contribute to a growing body of literature showing that PTSD symptoms are often comorbid with PND symptoms (Alcorn et al., 2010; Denis et al., 2011; Iles, Slade, \& Spiby, 2011; Lyons, 1998a; Maggioni, Margola, \& Filippi, 2006). In this sample, more women with PTSD symptoms also had PND symptoms, whereas there were fewer women who had PND symptoms who also had PTSD symptoms. Specifically, less than a third of women with PND symptoms also had PTSD symptoms (28.6\%), while two-thirds of women with PTSD symptoms also had clinically significant PND symptoms (66.7\%). The 
high percentage of PTSD women with PND symptoms is consistent with previous studies (Parfitt \& Ayers, 2009; White et al., 2006). It may be that depression was present before the traumatic event and consequently intensifies PTSD symptoms; or that depression is linked with the event itself; or is a sequela of unresolved PTSD symptoms (Lyons, 1998b).

In the current study PTSD symptoms correlated with avoidant coping, but not with problem- or emotion-focused coping styles. Of avoidant coping styles, PTSD symptoms were significantly related to denial, behavioural disengagement, and selfblame. These findings are consistent with previous research which show that dysfunctional coping strategies are strongly associated with PTSD symptoms in parturient women (Söderquist et al., 2009; Soet et al., 2003), soldiers (Solomon, Mikulincer, \& Avizur, 1988), and people with myocardial infarction (Ayers, Copland, \& Dunmore, 2009a). It has been established that avoidant coping, but not emotional- and problem-focused coping, correlated with PTSD symptoms in soldiers surviving an avalanche (Johnsen, Eid, Laberg, \& Thayer, 2002). The current study found that the three avoidant coping strategies of denial, behavioural disengagement, and self-blame were related to PTSD symptoms, which is not surprising as these styles are consistent with PTSD avoidance symptoms. Avoidant coping strategies are thought to impede the processing and habituation of the trauma memory (Pineles et al., 2011). In comparison, substance misuse was not related to PTSD symptoms, which might be due to the low frequency of as substance misuse as a form of coping in this sample of postnatal women. However, the findings of the current study suggest avoidant coping is not important once depression symptoms are taken into account. It is not clear why this is the case, however, it is possible that there is also some overlap between avoidant coping strategies, such as behavioural disengagement, and symptoms of depression.

On the other hand, depression symptoms were related to avoidant coping, emotional support, and lower levels of planning. Of avoidant coping styles, selfblame was a significant predictor of depression symptoms (even after PTSD symptoms were controlled for). This is consistent with previous studies. A recent longitudinal study showed that self-blame, along with other avoidant coping styles, such as self-distraction and substance use, was a significant predictor of PND 8 months after childbirth (Gutiérrez-Zotes et al., 2016). Women who use avoidance coping have 5 times higher risk for probable PND (Honey, Bennett, \& Morgan, 2003). Distancing and escape-avoidance were both related to higher PND symptoms (Faisal-Cury, Tedesco, Kahhale, Menezes, \& Zugaib, 2004; Vedovvi, Kenny, Gibson, Bowen, \& Starte, 2001); and immature defence style, which is a maladaptive coping style, was a predictor of depression symptoms even one year after childbirth (McMahon, Barnett, Kowalenko, \& Tennant, 2005). All these coping styles can prevent a person from dealing with the problem, which may foster or enhance depression symptoms. 
A number of limitations should be considered when interpreting the results from this study. A cross-sectional design was employed, which restricts causal inferences regarding the relationship between PTSD, PND, and coping. Longitudinal studies are needed to explore the temporal course of these variables. Recruitment of women during pregnancy would also allow the measurement of psychological problems before childbirth. The sample was also recruited via the Internet. Although time since giving birth was not related to the PTSD symptoms, confounding effects of memory bias cannot be excluded. Compared to the general population of parturient women in Croatia (Rodin, 2017), more women from the current study were primiparous and highly educated. Also, women who had an assisted vaginal delivery were overrepresented. Therefore, caution should be taken in generalising these results to the larger population. Notwithstanding, this is the first study to examine coping in relation to psychopathology symptoms following childbirth in Croatia.

Future research is needed to extend these findings. Specifically, studies should assess PTSD at several time points over the first postnatal year using a structured clinical interview as a gold standard. Also, more representative samples should be employed. Fathers should also be included in future studies. Previous research has shown that PTSD symptoms are highly correlated within couples (Ayers, Wright, \& Wells, 2007; Iles et al., 2011), and that a partner's acute stress reaction immediately after childbirth may be predictive of woman's PTSD symptoms at six and 12 weeks postnatal (Iles et al., 2011). Therefore, it is important to look at dyadic relations between mothers and fathers and provide interventions to the couple as a family unit. Finally, the majority of studies on postnatal mental health have focused on negative outcomes. However, positive psychological outcomes after childbirth have also been reported, such as psychological growth after traumatic events. For example, third of parturient women in Croatia and up to a half of parturient women in the UK experienced at least moderate growth after childbirth (Sawyer, Ayers, Young, Bradley, \& Smith, 2012; Sawyer et al., 2015). Therefore, future studies should measure both negative and positive psychological outcomes after childbirth.

\section{Conclusions}

Despite the online sampling and cross-sectional design, the rate of PTSD symptoms following childbirth in Croatian mothers in our sample is consistent with the previous literature, with $23.1 \%$ of women fulfilling Criterion A for PTSD and $1.9 \%$ of women with severe PTSD symptoms. Avoidant coping styles were found to correlate with both PTSD and PND symptoms. Future studies are needed in order to encompass a more representative sample of women and to specify important predictors of PTSD following childbirth in Croatian women. Since PTSD can have detrimental consequences, including a negative impact on the parent-baby bond (Parfitt \& Ayers, 2009), healthcare professionals need to be aware of the potential of PTSD following birth. Screening for postnatal psychopathological symptoms should 
be performed both for PND and PTSD symptoms, especially because there are women with PTSD symptoms who are not depressed, which could be missed otherwise. Screening for PTSD symptoms could be performed one month after childbirth in order to identify mothers who need an additional referral to mental health care practitioners (Lyons, 1998b).

\section{References}

Alcorn, K. L., O'Donovan, A., Patrick, J. C., Creedy, D., \& Devilly, G. J. (2010). A prospective longitudinal study of the prevalence of post-traumatic stress disorder resulting from childbirth events. Psychological Medicine, 40(11), 1849-1859.

American Psychiatric Association. (2013). Diagnostic and statistical manual of mental disorders (5th ed.). Arlington, VA: American Psychiatric Association.

Andersen, L. B., Melvaer, L. B., Videbech, P., Lamont, R. F., \& Joergensen, J. S. (2012). Risk factors for developing post-traumatic stress disorder following childbirth: A systematic review. Acta Obstetricia et Gynecologica Scandinavica, 91(11), 1261-1272.

Ayers, S., Bond, R., Bertullies, S., \& Wijma, K. (2016). The aetiology of post-traumatic stress following childbirth: A meta-analysis and theoretical framework. Psychological Medicine, 46(6), 1121-1134.

Ayers, S., Copland, C., \& Dunmore, E. (2009a). A preliminary study of negative appraisals and dysfunctional coping associated with post-traumatic stress disorder symptoms following myocardial infarction. British Journal of Health Psychology, 14(3), 459-471.

Ayers, S., Wright, D. B., \& Wells, N. (2007). Symptoms of post-traumatic stress disorder in couples after birth: Association with the couple's relationship and parent-baby bond. Journal of Reproductive and Infant Psychology, 25(1), 40-50.

Boorman, R. J., Devilly, G. J., Gamble, J., Creedy, D. K., \& Fenwick, J. (2013). Childbirth and criteria for traumatic events. Midwifery, 30(2), 255-261.

Brajenović-Milić, B., Martinac Dorčić, T., Kuljanić, K., \& Petrović, O. (2010). Stress and anxiety in relation to amniocentesis: Do women who perceive their partners to be more involved in pregnancy feel less stressed and anxious? Croatian Medical Journal, 51, 137-143.

Carver, C. (1997). You want to measure coping but your protocol's too long: Consider the Brief Cope. International Journal of Behavioral Medicine, 4, 92-100.

Corneil, W., Beaton, R., \& Murphy, S. (1999). Exposure to traumatic incidents and prevalence of posttraumatic stress symptomatology in urban firefighters in two countries. Journal of Occupational Health Psychology, 4(2), 131-141.

Cox, J. L., Holden, J. M, \& Sagovsky, R. (1987). Detection of postnatal depression: Development of the 10-item Ediburgh Postnatal Depression Scale. British Journal of Psychiatry, 150, 782-786. 
Creedy, D. K., Shochet, I. M., \& Horsfall, J. (2000). Childbirth and the development of acute trauma symptoms: Incidence and contributing factors. Birth, 27(2), 104-111.

Czarnocka, J., \& Slade, P. (2000). Prevalence and predictors of post-traumatic stress symptoms following childbirth. British Journal of Clinical Psychology, 39, 35-51.

Čuržik, D., \& Jokić-Begić, N. (2012). The utility of BDI-II in assessment of pre- and postpartum depression symptoms and their relation to labor pain. Psychiatria Danubina, 24(2), 167-174.

Denis, A., Parant, O., \& Callahan, S. (2011). Post-traumatic stress disorder related to birth: A prospective longitudinal study in a French population. Journal of Reproductive and Infant Psychology, 29(2), 125-135.

Ehlers, A., \& Clark, D. M. (2000). A cognitive model of posttraumatic stress disorder. Behaviour Research and Therapy, 38, 319-345.

Endler, N. S., \& Parker, J. D. A. (1990). Multidimensional assessment of coping: A critical evaluation. Journal of Personality and Social Psychology, 58, 844-854.

Faisal-Cury, A., Tedesco, J. J. A., Kahhale, S., Menezes, P. R., \& Zugaib, M. (2004). Postpartum depression: In relation to life events and patterns of coping. Archives of Women's Mental Health, 7(2), 123-131.

Folkman, S., \& Lazarus, R. (1980). An analysis of coping in a middle-aged community sample. Journal of Health and Social Behavior, 21, 219-239.

Ghorbani, M., Dolatian, M., Shams, J., Alavi-Majd, H., \& Travakolian, S. (2014). Factors associated with posttraumatic stress disorder and its coping styles in parents of preterm and full-term infants. Global Journal of Health Science, 6(3), 65-73.

Grekin, R., \& O'Hara, M. W. (2014). Prevalence and risk factors of postpartum posttraumatic stress disorder: A meta-analysis. Clinical Psychology Review, 34(5), 389-401.

Gutiérrez-Zotes, A., Labad, J., Martín-Santos, R., García-Esteve, L., Gelabert, E., Jover, M., ... Gratacós, M. (2016). Coping strategies for postpartum depression: A multi-centric study of 1626 women. Archives of Women's Mental Health, 19(3), 455-461.

Honey, K. L., Bennett, P., \& Morgan, M. (2003). Predicting postnatal depression. Journal of Affective Disorders, 76(1), 201-210.

Horowitz, M., Wilner, N., \& Alvarez, W. (1979). Impact of Event Scale: A measure of subjective stress. Psychosomatic Medicine, 41(3), 209-218.

Hudek-Knežević, J., Kardum, I., \& Vukmirović, Z. (1999). The structure of coping styles: A comparative study Croatian sample. European Journal of Personality, 13, 149-161.

Iles, J., Slade, P., \& Spiby, H. (2011). Posttraumatic stress symptoms and postpartum depression in couples after childbirth: The role of partner support and attachment. Journal of Anxiety Disorders, 25, 520-530.

Johnsen, B. H., Eid, J., Laberg, J. C., \& Thayer, J. F. (2002). The effect of sensitization and coping style on post-traumatic stress symptoms and quality of life: Two longitudinal studies. Scandinavian Journal of Psychology, 43, 181-188. 
Jokić-Begić, N., Žigić, L., \& Nakić Radoš, S. (2013). Anxiety and anxiety sensitivity as predictors of fear of childbirth: Different patterns for nulliparous and parous women. Journal of Psychosomatic Obstetrics \& Gynecology, 35(1), 22-28.

Kline, R. B. (2005). Principles and practice of structural equation modeling (2nd ed.). New York: Guilford.

Ljubotina, D., \& Muslić, Lj. (2003). Convergent validity of four instruments measuring posttraumatic stress disorder. Review of Psychology, 10(1), 11-21.

Lyons, S. (1998a). A prospective study of posttraumatic stress symptoms 1 month following childbirth. Journal of Reproductive and Infant Psychology, 16, 91-105.

Lyons, S. (1998b). Post-traumatic stress disorder following childbirth: Causes, prevention and treatment. In S. Clement (Ed.), Psychological perspectives on pregnancy and childbirth (pp. 123-143). Edinburgh, UK: Churchill Livingstone.

Maggioni, C., Margola, D., \& Filippi, F. (2006). PTSD, risk factors, and expectations among women having a baby: A two-wave longitudinal study. Journal of Psychosomatic Obstetrics \& Gynecology, 27(2), 81-90.

McMahon, C., Barnett, B., Kowalenko, N., \& Tennant, C. (2005). Psychological factors associated with persistent postnatal depression: past and current relationships, defence styles and the mediating role of insecure attachment style. Journal of Affective Disorders, 84(1), 15-24.

Nakić, S., Tadinac, M., \& Herman, R. (2009). Uloga percipiranog stresa i stilova suočavanja $\mathrm{u}$ nastanku predporođajne anksioznosti [The role of perceived stress and coping styles in development of prenatal anxiety]. Klinička psihologija, 2(1-2), 7-21.

Nakić Radoš, S., Košec, V., \& Gall, V. (2013a). Psychological effects of prenatal diagnostics: Maternal anxiety before and after the procedures. Prenatal Diagnosis, 33(12), 11941200 .

Nakić Radoš, S., Tadinac, M., \& Herman, R. (2013b). Screening for postpartum depression with the Croatian version of the Edinburgh Postnatal Depression Scale. Suvremena psihologija, 16(2), 203-218.

Nakić Radoš, S., Herman, R., \& Tadinac, M. (2016). Is the predictability of new-onset postpartum depression better during pregnancy or in the early postpartum period? A prospective study in Croatian women. Health Care for Women International, 37(1), 2344.

Olde, E., Kleber, R., van der Hart, O., \& Pop, V. (2006a). Childbirth and posttraumatic stress responses: A validation study of The Dutch Impact of Event Scale - Revised. European Journal of Psychological Assessment, 22, 259-267.

Olde, E., van der Hart, O., Kleber, R., \& van Son, M. (2006b). Posttraumatic stress following childbirth: A review. Clinical Psychology Review, 26(1), 1-16.

Olde, E., van der Hart, O., Kleber, R. J., van Son, M., Wijnen, H. A. A., \& Pop, V. J. M. (2005). Peritraumatic dissociation and emotions as predictors of PTSD symptoms following childbirth. Journal of Trauma \& Dissociation, 6, 125-142. 
Parfitt, Y., \& Ayers, S. (2009). The effect of postnatal symptoms of post-traumatic stress and depression on the couple's relationship and parent-baby bond. Journal of Reproductive and Infant Psychology, 27(2), 127-142.

Pineles, S. L., Mostoufi, S. M., Ready, C. B., Street, A. E., Griffin, M. G., \& Resick, P. A. (2011). Trauma reactivity, avoidant coping, and PTSD symptoms: A moderating relationship? Journal of Abnormal Psychology, 120(1), 240-246.

Powell, S., \& Duraković-Belko, E. (Eds.) (2002). Sarajevo 2000: The psychosocial consequences of war. Results of empirical research from the territory of former Yugoslavia. Sarajevo: UNICEF. Retrieved from http://www.psih.org.

Reić Ercegovac, I., \& Penezić, Z. (2011). Zadovoljstvo životom, depresivnost i stres kod žena tijekom trudnoće i prve godine postpartalno - uloga osobina ličnosti, zadovoljstva brakom i socijalne podrške. [Life satisfaction, depression and stress in women during pregnancy and first year postpartum - the role of personality traits, marital satisfaction and social support]. Klinička psihologija, 4(1-2), 5-22.

Rodin, U. (2017). Porodi u zdravstvenim ustanovama u Hrvatskoj 2016. godine. [Childbirth in health institutions in Croatia in2016]. Zageb: Hrvatski zavod za javno zdravstvo. Retrieved from https://www.hzjz.hr/wp-content/uploads/2017/08/Porodi_2016.pdf

Sawyer, A., Ayers, S., Young, D., Bradley, R., \& Smith, H. (2012). Posttraumatic growth after childbirth: A prospective study. Psychology \& Health, 27(3), 362-377.

Sawyer, A., Nakić Radoš, S., Ayers, S., \& Burn, E. (2015). Personal growth in UK and Croatian women following childbirth: A preliminary study. Journal of Reproductive and Infant Psychology, 33(3), 294-307.

Schnider, K., Elhai, J., \& Gray, M. (2007). Coping style use predicts posttraumatic stress and complicated grief symptoms severity among college students reporting a traumatic loss. Journal of Counseling Psychology, 54, 344-350.

Söderquist, J., Wijma, B., Thorbert, G., \& Wijma, K. (2009). Risk factors in pregnancy for post-traumatic stress and depression after childbirth. International Journal of Obstetrics and Gynaecology, 116, 672-680.

Soet, J. E., Brack, G. A., \& Dilorio, C. (2003). Prevalence and predictors of women's experience of psychological trauma during childbirth. Birth, 30, 36-46.

Solomon, Z., Mikulincer, M., \& Avizur, E. (1988). Coping, locus of control, social support, and combat-related posttraumatic stress disorder: A prospective study. Journal of Personality and Social Psychology, 55(2), 279-285.

Srkalović Imširagić, A., Begić, D., Šimičević, L., \& Bajić, Ž. (2017). Prediction of posttraumatic stress disorder symptomatology after childbirth - A Croatian longitudinal study. Women and Birth, 30(1), e17-e23.

Tedstone, J. E., \& Tarrier, N. (2003). Posttraumatic stress disorder following medical illness and treatment. Clinical Psychology Review, 23(3), 409-448. 
Veddovi, M., Kenny, D. T., Gibson, F., Bowen, J., \& Starte, D. (2001). The relationship between depressive symptoms following premature birth, mothers' coping style, and knowledge of infant development. Journal of Reproductive and Infant Psychology, 19(4), 313-323.

Verreault, N., Da Costa, D., Marchand, A., Ireland, K., Banack, H., Dritsa, M., \& Khalifé, S. (2012). PTSD following childbirth: A prospective study of incidence and risk factors in Canadian women. Journal of Psychosomatic Research, 73(4), 257-263.

White, T., Matthey, S., Boyd, K., \& Barnett, B. (2006). Postnatal depression and posttraumatic stress after childbirth: Prevalence, course and co-occurrence. Journal of Reproductive and Infant Psychology, 24(2), 107-120.

World Health Organization. (2013). World health statistics 2013. Retrieved from http://apps.who.int/iris/bitstream/10665/81965/1/9789241564588_eng.pdf?ua=1

World Health Organization. (2014). Trends in maternal mortality: 1990 to 2013. Estimates by WHO, UNICEF, UNFPA, The World Bank and the United Nations Population Division. Retrieved from http://apps.who.int/iris/bitstream/10665/112682/2/ 9789241507226_eng.pdf?ua=1

World Health Organization. (2015). Trends in maternal mortality: 1990 to 2015: estimates by WHO, UNICEF, UNFPA, World Bank Group and the United Nations Population Division. Retrieved from http://www.refworld.org/docid/5645ae384.html

\section{Stilovi suočavanja povezani sa simptomima posttraumatskog stresa i depresije nakon porođaja kod hrvatskih žena}

Porođaj je normativni čin u životu žene i uglavnom se smatra pozitivnim događajem. Međutim, svaka treća žena doživi porođaj kao tjelesnu prijetnju za sebe i/ili za svoje novorođenče te $3 \%$ žena nakon porođaja razvije posttraumatski stresni poremećaj (PTSP). Dosadašnja istraživanja upućuju na to da su slabe strategije suočavanja povezane s PTSP-om nakon porođaja, međutim, ta su se istraživanja uglavnom koristila jednodimenzionalnim mjerama strategija suočavanja. Drugim riječima, tek valja ispitati koje specifične dimenzije suočavanja pridonose PTSP-u nakon porođaja. Ciljevi su ovog istraživanja ispitati simptome PTSP-a nakon porođaja te kako su različiti stilovi suočavanja povezani sa simptomima PTSP-a i depresije kod žena u Hrvatskoj. Žene $(N=160)$ koje su rodile unatrag dvije godine ispunile su online upitnik koji mjeri simptome PTSP-a (Impact of Event Scale - IES), poslijeporođajnu depresiju (Edinburgh Postnatal Depression Scale - EPDS) te stilove suočavanja (Brief Cope). U ovom je uzorku $1.9 \%$ ispitanica izvijestilo o ozbiljnim simptomima PTSP-a nakon porođaja, a $21.9 \%$ ih je izvijestilo o depresivnim simptomima. Većina je žena (66.7 \%) sa simptomima PTSP-a izvijestila i o depresivnim simptomima. S druge strane, 28.6 \% žena s depresivnim simptomima također je izvijestilo i o simptomima PTSP-a, što upućuje na viši komorbiditet PTSP-a i depresije nego obrnuto. Od izbjegavajućih su stilova suočavanja poricanje i samookrivljavanje pozitivno korelirali sa simptomima PTSP-a i depresije, dok je odustajanje pozitivno koreliralo samo sa simptomima PTSP-a, a odvraćanje pažnje sa simptomima depresije. Također, niže razine planiranja i više razine emocionalne podrške bile su povezane $s$ višom razinom depresivnosti. Međutim, nakon kontroliranja poslijeporođajnih psihopatoloških simptoma stilovi suočavanja nisu bili značajni prediktori simptoma PTPS-a, ali je samookrivljavanje bilo značajni prediktor depresivnih simptoma. Žene u Hrvatskoj izvještavaju o 
psihopatološkim simptomima nakon porođaja te su oni povezani sa stilovima suočavanja. Izbjegavajući stil suočavanja, samookrivljavanje, posebno je povezan s depresivnim simptomima. Buduća bi istraživanja trebala ispitati prediktore PTSP-a kod hrvatskih žena u reprezentativnijim uzorcima $\mathrm{u}$ trudnoći te $\mathrm{s}$ praćenjem nakon porođaja. Također, probir za poslijeporođajne psihopatološke simptome trebao bi se provoditi i za simptome depresije i za simptome PTSP-a.

Ključne riječi: posttraumatski stresni poremećaj (PTSP), porođaj, depresija, suočavanje

\title{
Estilos de afrontamiento relacionados con el estrés postraumático y los síntomas de depresión en las croatas después del parto
}

\begin{abstract}
Resumen
El parto es un acontecimiento normativo en la vida de la mujer y se considera un acontecimiento positivo. Sin embargo, una de tres mujeres percibe el parto como una amenaza física para ella misma o su bebé y el 3\% de las mujeres desarrollan el trastorno por estrés postraumático (TEPT) después del parto. Malas estrategias de afrontamiento se han asociado con el TEPT posparto. Sin embargo, estudios previos mayormente utilizaban mediciones unidimensionales de estrategias de afrontamiento, por lo que queda por investigar qué dimensiones específicas de afrontamiento son más predictivas del TEPT posparto. Los objetivos de este estudio fueron explorar si las mujeres en Croacia informan de los síntomas TEPT posparto y cómo se relacionan diferentes estilos de afrontamiento con el TEPT y los síntomas de depresión. Las mujeres $(N=160)$ que han dado a luz en los últimos dos años completaron un cuestionario en línea que mide los síntomas TEPT (Escala del Impacto de Sucesos - E.I.E.), los síntomas de depresión postnatal (Escala de Depresión de Postparto de Edimburgo - EDPE) y los estilos de afrontamiento (Brief Cope). En esta muestra, el $1.9 \%$ informó de los síntomas TEPT posparto graves y el $21.9 \%$ informó de los síntomas de depresión. Muchas mujeres (66.7\%) con los síntomas TEPT informaron también de los síntomas de depresión. Por otra parte, el $28.6 \%$ de las mujeres con síntomas de depresión, también informaron de los síntomas TEPT, mostrando que hay una mayor comorbilidad del TEPT y la depresión, que viceversa. Estilos evasivos de afrontamiento, en concreto, la negación y la auto-culpa, se han correlacionado positivamente tanto con el TEPT, como con los síntomas de depresión. Es más, de todos los estilos evasivos de afrontamiento, la auto-culpa y la desconexión conductual se han correlacionado positivamente sólo con los síntomas de TEPT, mientras que la auto-distracción se ha correlacionado positivamente sólo con los síntomas de depresión. Además, los niveles más bajos de planificación y los niveles más altos de apoyo emocional se han relacionado con los niveles más altos de depresión. Sin embargo, los estilos de afrontamiento no fueron predictores significativos de los síntomas de TEPT, pero auto-culpa fue un predictor significativo de los síntomas de depresión. Las croatas informan de los síntomas psicopatológicos después del parto, que se relacionan con estilos de afrontamiento. El estilo evasivo de afrontamiento, la auto-culpa, se asocia particularmente con los síntomas de depresión. Los futuros estudios deberían investigar los predictores del TEPT posparto de las croatas en muestras más representativas durante el embarazo y también después del parto. Además, las investigaciones de síntomas psicopatológicos postnatales se deberían llevar a cabo tanto para la depresión, como para los síntomas de TEPT.
\end{abstract}

Palabras clave: trastorno por estrés postraumático, TEPT, parto, depresión, afrontamiento

Primljeno: 28.02.2018. 